\title{
Investigating Cognitive and Psycholinguistic Features of Translation Universals
}

\section{Дослідження когнітивних і психолінгвальних рис перекладних закономірностей}

\author{
Serhii Zasiekin \\ Ph.D. in Linguistics, \\ Professor
}

\author{
Сергій Засскін \\ кандидат філологічних наук, \\ професор
}

\author{
E-mail: s.zasyekin@gmail.com \\ orcid.org/0000-0001-9453-3534 \\ Scopus Author ID: 35112194200 \\ ResearcherID: C-3094-2016
}

\author{
Lesya Ukrainka Eastern \\ European National University \\ 13, Voli Avenue, Lutsk, \\ Ukraine, 43025
}

Східноєвропейський національний університет імені Лесі Украӥнки

$\triangle$ пр. Волі, 13, Луцьк, Україна, 43025

\section{Original manuscript received October 12, 2018 \\ Revised manuscript accepted October 14, 2019}

\begin{abstract}
Traditionally, translation is viewed as a reliable shield over linguistic diversity, one of the ways to ensure a target language survival. However, translation is also reported to distort a translated language due to introducing 'the third code' (Frawley, 1984) features. These "deforming tendencies» (Berman, 1985) destroy the translated language by erasing its natural pattern and by adding there a bundle of alien features that cause its lexical, syntactical, and stylistic deficiencies. The current study is aimed at detecting those destructive features treated in translation studies as "translation universals" (Chesterman, 2004). To this end, a psycholinguistic analysis was held to establish the use of language which is not the result of intentional, controlled processes and of which translators may not be aware. These subliminal translation-inherent processes can be traced in the use of function words that
\end{abstract}


encode procedural meaning. Relevance Theory (Wilson \& Sperber, 1993) explains a conceptual-procedural distinction as a major distinction made between two types of linguistically encoded information. Conceptual information expressed by content words is viewed as encoding concepts whereas words with procedural meaning contribute to the derivation of implicatures, certain ways of processing propositions. Discourse connectives, conjunctions, prepositions, particles, pronouns, modal words constitute that group of function words with procedural meaning. To uncover certain variations in the use of these linguistic units, a parallel English-Ukrainian corpus made up of an 8,000-character excerpt from Franny by J.D. Salinger, its professional translation, and forty novice translators' target versions, was compiled.

The corpus data were processed by Textanz and SPSS computerized tools.

The results of the psycholinguistic analysis proved that the Ukrainian versions as contrasted to the original text contained the following S-universals: implicitation expressed through the shortage of discourse markers of global coherence, simplification due to the lack of personal pronouns, decreased mean number of words per sentence, and greater number of sentences; normalization embodied in vernacular network impoverishment due to the decreased amount of pragmatic markers and fillers, explicitation due to higher lexical variety and density rates, and rationalization as a result of abundant marking of discourse relations.

Conclusions. Taken together, these findings have significant implications for the understanding of how procedural information processing by novice translators is manifested in translation.

Key words: relevance theory, translation universals, procedural/conceptual meaning.

\section{Вступ}

Упродовж читання художніх творів у перекладі на українську мову час від часу мене не полишало відчуття якоїсь незвичності, подекуди штучності тієї української, якою перекладач ретранслював авторські події, факти, наративи чи діалоги персонажів. Позірно ніби все в текстах було гаразд, навіть іноді «дуже» добре, проте щось таки виказувало, що українська версія - переклад, що має «особливі риси». Сподіваюся, моїм читачам також знайомі ці відчуття.

Емпіричні студії в межах дескриптивного перекладознавчого напряму 3 використанням паралельних двомовних та зіставних одномовних електронних корпусів англійської, фінської, данської, голландської та ін. мов (Olohan \& Baker, 2000; Laviosa-Braithwaite, 1996; Chesterman, 2004) доволі переконливо засвідчили про реальність існування «особливих рис» у більшості перекладів 
незалежно від операційних мов. У літературі феномен штучності і деформацій у мові перекладу одержав назву «трансляціонізму» (англ. translationese), «третього коду» (Frawley, 1984), що виникає на перетині двох мов - мови оригіналу (1-го коду) та мови перекладу (2-го коду).

«Деформувальні тенденції» в перекладацькій діяльності доволі розлого описав А. Берман (Berman, 1985), виокремивши, 3-поміж інших, такі найтиповіші: раціоналізацію - підвищення ступеня логічної зв'язності (когезії) та цілісності (когерентності) текстів перекладу (ПТ), експліцитацію - введення відсутньої в оригіналі додаткової інформації, нейтралізацію діалектів або екзотизацію, вилучення ідіом, зниження лексичної різноманітності тексту перекладу i т. ін. Г. Турі (Toury, 1995), спираючися на концепцію I. Евена-Зогара, називає такі тенденції законами (laws), Ш. Блум-Кулка (Blum-Kulka, 1986) - зсувами (shifts), Е. Честермен (Chesterman, 2004) - перекладними універсаліями (translation universals). Останній виокремлює серед них Д-універсалії та $Ц$-універсалії (в оригіналі: $S$-universals, $T$-universals). Д-універсалії зафіксовані у ПТ деформації в зіставленні із текстом-джерелом, Ц-універсалії - зафіксовані деформації в текстах цільовою мовою у зіставленні $з$ неперекладами цією ж мовою (Chesterman, 2011). Автор розширює перелік Д-універсалій, додаючи такі: збільшення довжини ПТ, порівняно з першоджерелом; інтерференцію джерельної мови; стандартизацію й скорочення повторів у ПТ; гіпотезу про повторні переклади. Потенційними Ц-універсаліями Е. Честермен уважає недостатню представленість специфічних для цільової мови одиниць; спрощення; нетипові лексичні моделі (Chesterman, 2011).

Попри надзвичайну популярність у сучасному перекладознавстві запозиченого з лінгвістики терміна «універсалія», він видається доволі невдалим, позаяк більшою мірою стосується виявлених емпіричним шляхом загальних тенденцій у перекладі. Отож під час дослідження згаданих деформацій послуговуватимуся надалі терміном «перекладні закономірності», оскільки він адекватніше відбиває сутність феномену спостережених у цільових версіях і відсутніх у першоджерелі лінгвальних рис, що відрізняють переклад(и) від оригіналу. До того ж, назва «закономірності» видається вдалішою за «закони» Г. Турі (Toury, 1995), бо дає змогу уникнути уявлення про наявність якихось обов'язкових 
Investigating Cognitive and Psycholinguistic Features of Translation...

для застосування у перекладацькій діяльності загальних принципів. Закони ж пояснюють, чому згадані мовні риси мають прояв у перекладі.

Серед головних причин значного розповсюдження згаданих тенденцій у перекладі С. Галверсон називає когнітивні, адже їхній характер пов'язаний зі способами обробки перекладачем мовного матеріалу (Halverson, 1998). Це означає, що джерела перекладних закономірностей слід шукати поза мовою чи мовами. Більшість дослідників погоджуються 3 тим, що ці лінгвальні риси мають недовільний характер (Olohan \& Baker, 2000). Для нашого дослідження вкрай важливо те, що їхній пошук не у змістових (мовних), а в процедурних аспектах перероблення мови виключить проблему інтерференції мов під час перекладацької діяльності. Цьому особливому критерію пошуку відповідає група мовних одиниць, чия функція полягає в кодуванні способів перероблення вербальної інформації ВТ. У теорії релевантності ці одиниці, що підлягають несвідомій (автоматичній) обробці перекладачем, одержали назву носіїв процедурного значення.

\section{Методологія дослідження}

Теорія релевантності. Теорія релевантності постулює існування двох базових типів вербально кодованої інформації: концептуальної та процедурної (Wilson \& Sperber, 1993), які різняться лінгвально й когнітивно. Концептуальну інформацію кодують лексичні одиниці - іменники, дієслова, прикметники, прислівники, тобто повнозначні (змістові) слова. Процедурну інформацію кодують нелексичні категорії, як-от: сполучники, прийменники, частки тощо. Із когнітивного погляду, концептуальна інформація формує концептуальні репрезентації, а процедурна інформація орієнтує адресата в умовивідних процедурах, які належить адресату виконати, аби визначити інтенції мовця (автора) (Blakemore, 2002).

Перелік носіїв процедурного значення не обмежений сполучниками, частками чи прийменниками. До їхньої категорії ввійшли так звані продукти «граматикалізації» (Nicolle, 1998) одиниці, що втратили первинне концептуальне значення і набули 
процедурного значення. Їхнім джерелом є змістові одиниці. Серед таких, наприклад, дискурсивні маркери well, I mean, listen, you know, so, anyway; модальні слова та вирази perhaps, certainly, I believe, to tell the truth тощо. Ці одиниці, внаслідок втрати концептуального й набуття процедурного значення, одержують статус диз'юнктів, бо більше не належать до пропозиційного змісту висловлень в дискурсі, виконуючи функцію «ключів» до належної інтерпретації суміжних або віддалених висловлень-пропозицій.

Видається важливим розмежовувати мовні одиниці, що передають процедурне значення, проте відповідають умовам істинності пропозиції (truth-conditions) і $є$ iі частиною, та ті, що також передають процедурне значення, але не належать до пропозиційного змісту (Wilson, 2011). Серед перших - займенники, що також є продуктами граматикалізації, функція яких полягає в допомозі адресатові виконати завдання референції (Nicolle, 1998). Серед других - згадані вище вигуки, частки, модальні слова, дискурсивні маркери, прийменники, сполучники, що пропонують чіткі процедури відносно конструювання експлікатур вищого порядку, формуючи або ставлення мовця (автора) до пропозиційного змісту, або з'єднуючи пропозиції в логічну послідовність (Alves \& Gonçalves, 2013: 111).

До цих мовних одиниць сьогодні прикута увага не лише лінгвістів, а й психолінгвістів і психологів. Так, соціальний психолог Дж. Пенебейкер називає всю групу носіїв процедурного значення функціональними, або «стильовими» словами, питома вага яких у актуальному дискурсі пересічного мовця сягає 3050\%, попри те, що в мові їхня кількість становить лише 500-600 слів (приблизно 0,5-0,6\%) від усіх слів у мові (Pennebaker, Boyd, Jordan \& Blackburn, 2015).

Якщо без сполучників та прийменників загалом важко уявити комунікацію й побудувати висловлення й дискурс загалом, то без вербальних сигналів когерентності - дискурсивних маркерів можна обійтися, тобто їхня наявність у мовленні - необов'язкова (optional). Водночас відсутність цих експліцитних сигналів здатна ускладнити комунікацію, бо знижує релевантність висловленого для адресата, який залишається без «дороговказів» до інтерпретації висловлень у дискурсі. 
Investigating Cognitive and Psycholinguistic Features of Translation...

Отже 3 погляду теорії релевантності, аби досягнути «оптимальної релевантності», автор (мовець) уводить сигналиінструкції, зменшуючи цим когнітивні зусилля й полегшуючи завдання адресата 3 пошуку інтенційованого відправником способу обробки пропозицій. Інакше кажучи, якщо мовні одиниціносії концептуальної інформації дають поштовх до обробки пропозиційного змісту висловлень, то носії процедурної інформації сприяють досягненню максимального когнітивного ефекту висловлень за мінімуму когнітивних зусиль 3 боку адресата, накладаючи морфо-синтаксичні обмеження на обробку висловлення. Із цієї перспективи, теорія релевантності визначає дихотомію концептуальної й процедурної інформації як таку, що скеровує умовивідний процес адресата в потрібне для автора річище (Alves, Gonçalves \& Szpak, 2014: 155)

Для нашого дослідження перекладних закономірностей вельми важливо те, що кодована змістовими словами концептуальна інформація доступна для свідомого (експліцитного) перероблення мозком. Натомість, процедурні одиниці - активізатори когнітивних процесів, не піддаються свідомій обробці, хіба що непрямим, метакогнітивним шляхом (Alves et al., 2016: 117). Водночас, як засвідчили експерименти зі стеження за рухом очей (еуеtracking), саме ці процедурні одиниці привертають левову частку перекладацької уваги й часу (Alves et al., 2016), бо вони активують глибинні процеси обробки висловлень ВТ згідно із закладеною в них відповідною «інструкцією». Інакше кажучи, самі ці одиниці не потребують часу на обробку, бо вхоплюються мозком автоматично, проте тригерують глибинний процес перероблення, на що потрібен час і когнітивні зусилля.

Експерименти Б. Дрегстед (Dragsted, 2010), спрямовані на спостереження за поведінкою професійних перекладачів i перекладачів-студентів на основі методу кілогініну (від англ.: kеу logging - натиснення клавіші на клавіатурі комп’ютера) доводять, що досвідчені тлумачі вдаються до інтегрованої координації процесів розуміння ВТ та породження ПТ, тобто паралельно-розподіленої обробки (ПРО) даних. Процедурні одиниці полегшують вертикальну (автоматичну) обробку у цих перекладачів, оскільки набір цих одиниць-сигналів способів обробки пропозицій скінченний i зрілими перекладачами добре засвоєний. Таку мовну компетентність 
M. Параді (Paradis, 2004) вважає імпліцитною, яку зберігає та відтворює імпліцитна пам'ять досвідчених перекладачів. Удаючись під час перекладу до інтегрованого підходу, вони здатні миттєво передбачити подальший хід подій у ВТ і обрати відповідний спосіб обробки, бо керуються ймовірнісним механізмом на основі відбитих у попередньому досвіді статистично частотніших зв'язків (конекцій) (Paradis, 2004: 8). Як зазначає Ф. Алвес, що досвідченіший перекладач, то більшу кількість імплікатур він здатен породити, аби вибрати ту, що викличе в кінцевого адресата максимальний (i, як правило, найточніший) когнітивний ефект за мінімальних зусиль (Alves \& Gonçalves, 2013).

На противагу професіоналам, новачки надають перевагу послідовному координуванню своїх когнітивних кроків із інтерпретації даних ВТ та породження ПТ під час фази синтезу (Hvelplund, 2017: 254). Пояснити такий підхід видається можливим через небагатий досвід (малу повторюваність перекладацьких дій) початківців, які в більшій мірі реагують на концептуальну інформацію й покладаються радше на експліцитні процедури металінгвістичні й прагматичні знання, керовані декларативною пам'яттю. Така стратегія суголосна 3 ідеєю М. Параді відносно того, що мовці, які вивчали другу мову після засвоєння рідної, компенсують прогалини шляхом частого звернення до металінгвістичних знань та прагматики (Paradis, 2009: x).

Отже об'єктом нашого дослідження постали носії процедурного значення, що через свої властивості не підлягають свідомому контролю з боку перекладача, а відтак не є джерелом інтерференції мови-джерела в мові перекладу. Предмет вивчення спостережені в діяльності новачків перекладні Д-закономірності під час відтворення художнього твору цільовою мовою. Мета з'ясувати мовні риси ПТ, відмінні від першоджерела, на основі наявних у ПТ маркерів процедурної інформації.

Матеріал та учасники. Оскільки запропоноване в цій статті дослідження Д-закономірностей - продовження започаткованого мною в низці попередніх праць психолінгвістичного вивчення мовленнєвої поведінки перекладачів-новачків (Zasiekin, 2014), матеріалом емпіричного дослідження слугували порівняльні дані англомовного художнього тексту та його перекладів українською мовою. Для цього в межах модуля самостійної роботи 40 студентам 
IV курсу бакалаврату спеціальності «Переклад» було запропоновано письмово перекласти українською уривок діалогу між головними героями твору Дж.Д. Селінджера (Salinger, 1964) «Френні» обсягом 8 тис. знаків. До початку перекладу всіх перекладачів було сгруповано в три групи носіїв конкретного когнітивного стилю (КС) - синтетичного, аналітичного чи проміжного (див. докладніше процедуру визначення: Засєкін, 2012).

Методи обробки даних. У дослідженні середньогрупових показників застосовано елементи описової статистики комп'ютерної програми SPSS 21 для Windows. Психолінгвістичний аналіз (ПЛА) текстів першоджерела, версії професійного перекладача Ю. Покальчука (Селінджер, 1984) та студентських версій здійснено iз застосуванням програми Textanz 2.3. Оскільки формування художнього потенціалу семантичного образу твору відбувається на кількох підрівнях, зокрема лексичному, стилістичному та морфолого-синтаксичному (Чередниченко, 2007), ПЛА здійснено 3 урахуванням таких показників:

- лексичні (кількість слів, лексичне розмаїття, лексична щільність, коефіцієнт читабельності тексту);

- стилістичні (кількість речень, їхня середня довжина в словах, дискурсивні маркери);

- синтаксичні (сурядність/підрядність зв'язку між ними, зв'язність тексту - сполучники, прийменники, займенники).

Отже серед мовних рис першоджерела та перекладів, які бралися до уваги під час ПЛА, обрано було такі: загальна кількість слів (NWORDS) та речень (NSENTENC), середній обсяг речень у словах (MEANWSEN), коефіцієнт лексичної різноманітності (LEXVAR), лексична щільність (LEXDENS), коефіцієнт прагматичної маркованості (PRAGMARK), кількість дискурсивних маркерів глобальної когерентності (DMGLOBAL), сполучників сурядності (NCOORD), підрядності (NSUBORD). За основу показника ступеня читабельності тексту (READABIL) під час ПЛА на лексичному рівні за брався Automated Readability Index (ARI) (Smith \& Senter, 1967): що вищий $A R I$, то складніший текст для розуміння адресатом. Формула для обрахунку $A R I$ не прив'язана до конкретної мови, тому виявляе надійність і для українськомовного тексту: $4.71\left(\frac{\text { characters }}{\text { words }}\right)+0.5\left(\frac{\text { words }}{\text { sentences }}\right)-21.43$. 
Дослідження когнітивних і психолінгвальних рис перекладних...

Коефіцієнт лексичного розмаїття LEXVAR свідчить про особливості використання автором способу представлення інформації: спрощеного (стереотипізованого) чи ускладненого, оскільки ми маємо справу з текстом з інкорпорованим діалогічним дискурсом, природно припустити, що зазначений показник, а відтак і показник лексичної щільності LEXDENS буде меншим. Крім того, у діалозі беруть участь комуніканти 3 романтичними стосунками. Тому ступінь соціальної та психологічної дистанції між ними наближений до нуля.

\section{Результати та дискусії}

\section{Лексичні показники Д-закономірностей}

Аналіз українськомовних версій, виконаних студентами, та їхнє зіставлення 3 оригіналом загалом підтверджує наявність конкретних переваг перекладачів, набору тенденцій/відношень між ВТ та ПТ. Результати ПЛА текстів сорока цільових версій (табл. 1) засвідчили таке: кількість слів NWORDS помітно менша у текстах перекладу, що підвищило коефіцієнти LEXVAR та LEXDENS.

Таблиця 1. Середньогрупові результати ПЛА текстів перекладу програмою SPSS за лексичними показниками $(\mathrm{n}=40)$

\begin{tabular}{lcc}
\hline \multicolumn{1}{c}{ Variables } & $\begin{array}{c}\text { Mean } \\
\text { (SD) }\end{array}$ & $\begin{array}{c}\text { Min- } \\
\text { Max }\end{array}$ \\
\hline \multirow{2}{*}{ NWORDS } & 1611.10 & 1450.00 \\
& $(62.36)$ & 1719.00 \\
LEXVAR & 22.83 & 21.40 \\
& $(.64)$ & 24.20 \\
LEXDENS & .46 & .43 \\
& $(.013)$ & .48 \\
READABIL & 5.94 & 4.87 \\
& $(.50)$ & 6.76 \\
\hline
\end{tabular}

Примітка: Меап=середньогрупові значення, $S D=$ стандартне відхилення, Міп=мінімальне значення, Мах= максимальне значення, $n=$ =кількість українських перекладів.

Табл. 2 демонструє лексичні показники першоджерела та перекладу Ю. Покальчука: 
Investigating Cognitive and Psycholinguistic Features of Translation...

Таблиця 2. ПЛА лексичних показників тексту-оригіналу та перекладу Ю. Покальчука

\begin{tabular}{lcc}
\hline \multicolumn{1}{c}{ Variables } & J.D. Salinger & Ю. Покальчук \\
\hline NWORDS & 1717.00 & 1695.00 \\
LEXVAR & 17.00 & 25.50 \\
LEXDENS & 0.34 & 0.51 \\
READABIL & 4.12 & 6.93 \\
\hline
\end{tabular}

Дж. Селінджер, вочевидь, оперує частотнішими, знайомішими англомовному читачеві словами. Проте, як бачимо, цю лексичну стратегію здебільшого не збережено ані в перекладах досліджуваної групи, ані в Ю. Покальчука, котрий має найвищий серед цільових версій цей показник. Тому ця спільна тенденція збільшення LEXVAR одержує статус експліцитації як однієї 3 лексичних Д-закономірностей під час перекладу обраного уривка художнього твору.

Аналіз результатів кореляційного аналізу в групі досліджуваних (табл. 3) засвідчив позитивний значущий зв'язок між коефіцієнтами LEXVAR, LEXDENS та ступенем читабельності тексту READABIL: що вища лексична щільність (розмаїття), то складніший текст для розуміння.

Таблиця 3. Результати кореляційного аналізу (2-tailed Pearson r)

\begin{tabular}{lcccc}
\hline \multicolumn{1}{c}{ Variables } & NWORDS & LEXVAR & LEXDENS & READABIL \\
\hline NWORDS & 1 & -.196 & -.216 & -.113 \\
LEXVAR & -.196 & 1 & $.976(* *)$ & $.528(* *)$ \\
LEXDENS & -.216 & $.976(* *)$ & 1 & $.548(* *)$ \\
READABIL & -.113 & $.528(* *)$ & $.548(* *)$ & 1 \\
\hline
\end{tabular}

Примітка: ** кореляція значуща на рівні $p=0.01$ (2-tailed)

\section{Стилістичні показники Д-закономірностей}

Однією 3 провідних рис стилю автора $є$ послуговування дискурсивними маркерами (Schiffrin, 1987). Дискурсивні маркери (ДМ) утворюють окрему групу мовних одиниць носіїв процедурного значення, функціональним призначенням яких $€$ індикація когерентних зв'язків між двома й більше висловленнями-реченнями. Їхня інструментальна функція не обмежена одним висловленням. 
Ці продукти граматикалізації охоплюють не лише сполучники чи прийменникові сполуки, а й прислівники, дієслова, дієприслівникові звороти зі стертим концептуальним значенням, наприклад: so (отож, отже), then (потім, після того), апушау (втім, у будь-якому разі, тож), now (mепер), well, as I said (ось, як я вже каза(в)ла), I mеan (тобто, інакше кажучи), уои know/see (знаєш/бачиш), well (ну), the thing is (річ у тім), as a matter of fact (фактично, власне кажучи), by the way (між іншим).

Концептуальним профілем дискурсивних маркерів $\epsilon$ позначення локального або глобального відношення когерентності між сегментами діалогу. ПЛА брав до уваги ДМ глобальної когерентності (DMGLOBAL), що беруть участь в організації тематичної мережі дискурсу. Ще однією групою для ПЛА обрано було прагматичні (недискурсивних) маркери (PRAGMARK), які охоплюють вставні слова, вирази, вигуки, прислівники, повтори, заповнювачі пауз (fillers) тощо (табл. 4). Серед заповнювачів пауз були, наприклад, одиниці sort of, I don't know, really, oh.

Таблиця 4. Середньогрупові результати ПЛА текстів перекладу програмою SPSS за стилістичними показниками $(\mathrm{n}=40)$

\begin{tabular}{lcc}
\hline Variables & $\begin{array}{c}\text { Mean } \\
\text { (SD) }\end{array}$ & $\begin{array}{c}\text { Min- } \\
\text { Max }\end{array}$ \\
\hline \multirow{2}{*}{ NSENTENC } & 169.78 & 144.00 \\
& $(10.48)$ & 191.00 \\
MEANWSEN & 9.48 & 8.18 \\
& $(.66)$ & 11.00 \\
DMGLOBAL & 27.45 & 13.00 \\
PRAGMARK & $(9.33)$ & 54.00 \\
& 34.83 & 18.00 \\
\hline
\end{tabular}

Примітка: Меап=середньогрупові значення, $S D=$ стандартне відхилення, Міп=мінімальне

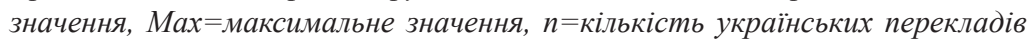

Як бачимо, під час перекладу твору недосвідченими перекладачами зафіксовано тенденцію до імпліцитації - зменшення кількості дискурсивних маркерів тематичної мережі DMGLOBAL. Водночас, бачимо нормалізацію, адже показники свідчать про зменшення кількості відтворених прагматичних маркерів та 
Investigating Cognitive and Psycholinguistic Features of Translation...

заповнювачів пауз PRAGMARK. Відбулися процеси, зворотні тим, про які згадує О. Чередниченко: «Не можна підміняти домінантну нейтральність художнього дискурсу показною розмовністю, бо вона (нейтральність) може бути важливим зображувальним засобом» (Чередниченко, 2007: 26). У нашому випадку саме авторська ненейтральність (табл. 5) є таким стилістичним засобом, здебільшого знехтувана перекладачами-початківцями досліджуваної вибірки. Порівняння даних оригіналу й перекладу Ю. Покальчука свідчить про схожу тенденцію до імпліцитації та нормалізації:

Таблиця 5. ПЛА стилістичних показників тексту-оригіналу та перекладу Ю. Покальчука

\begin{tabular}{lcc}
\hline \multicolumn{1}{c}{ Variables } & J.D. Salinger & Ю. Покальчук \\
\hline NSENTENC & 158.00 & 167.00 \\
MEANWSEN & 10.26 & 10.15 \\
DMGLOBAL & 40.00 & 30.00 \\
PRAGMARK & 52.00 & 37.00 \\
\hline
\end{tabular}

Щодо внутрішньогрупових показників, зазначимо вищі за середньогрупові показники PRAGMARK тексту-оригіналу в молодих перекладачів, які тяжіють до полюса «імпульсивність» КС «імпульсивність - рефлективність». Перекладачі 3 широким діапазоном еквівалентності КС «вузький - широкий діапазон еквівалентності» демонструють тенденцію до застосування стратегії глобальної когерентності, виявом якої є вищий показник DMGLOBAL. Ця закономірність свідчить про краще координування й керування ними тематичними сегментами тексту.

Решта перекладачів - аналітичного КС із полюсами «рефлективність» та «вузький діапазон еквівалентності», а також проміжного (аналітико-синтетичного) КС на стилістичному рівні виявили тенденцію до спрощення. Так, Дж. Селінджер у діалозі персонажів використовує найчастіше займенник 1-ї особи $I$ (42) та 2-ї особи уои (41), а займенник 3-ї особи he майже вдвічі рідше 22 випадки. У тексті перекладу Ю. Покальчука простежується збалансована картина, проте дискурс стає зорієнтованіший на 2-гу особу: ти/тобі/тебе/тобою (31), я/мене (29), займенник 3-ї особи він не набагато поступається - 18 слововжитків. У перекладах досліджуваної групи новачків загалом зафіксовано 
Дослідження когнітивних і психолінгвальних рис перекладних...

чисельне зниження показників послуговування займенниками 1-ї та 2-ї особи за збереженого займенника він. Частково це викликано відмовою перекладачів від відтворення форми $я$ маю на увазі/думиз як еквівалента I mean, що разом iз you know уходять до складу PRAGMARK та DMGLOBAL. Наслідком цього є поява у ПТ «статусної маркованості» (Карасик, 1992), тобто небажаного збільшення соціальної та психологічної дистанції між співрозмовниками в цільових версіях діалогу.

\section{Синтаксичні показники Д-закономірностей}

Синтаксична структура, як зауважує О.М. Фінкель, - один із надзвичайно важливих компонентів художнього твору, адже «добір типу речень - простих, складносурядних, складнопідрядних, i вживання зв'язків сполучникових чи безсполучникових, і порядок слів, і застосування лексико-синтаксичних повторів <..> все це перекладач повинен відтворити 3 не меншою дбайливістю, ніж лексику і семантику» (Черноватий \& Карабан, 2007: 286). Відтак особливої ваги набуває установлення того, чи зберігається той синтаксичний «ключ», у якому створено художній текст.

Як показали дослідження М. Айрленд і колег (Ireland, Slatcher, Eastwick \& Pennebaker, 2011), що більше в мовленні співрозмовників однакових займенників, сполучників, прийменників, дискурсивних маркерів, то вищим є ступінь інтимізації комунікантів. Діалог між Лейном Кутелом та Френні в тексті першотвору зафіксував велику кількість спільних лінгвальних одиниць зазначених класів.

Ці чинники потрібно було враховувати й під час перекладу задля досягнення схожого естетичного ефекту на українського читача. Разом із тим, беремося стверджувати, що якщо перекладач зберігає спільність цих одиниць із ВТ у цільовій версії, це може свідчити на користь вищого ступеня його «інтимізації», або зближення з автором першоджерела. Зіставний ПЛА доводить стійкі відмінності між першотвором та текстами перекладів (табл. 6).

Описовий аналіз програми SPSS установив вищі середньогрупові показники і за параметром кількості сполучників сурядності NCOORD, i підрядності NSUBORD, що загалом підвищило показник зв'язності COHESION цільових версій. Отже, бачимо експліцитацію, тобто маркування зв'язків між реченнями, 
Investigating Cognitive and Psycholinguistic Features of Translation...

а також раціоналізацію - підвищення ступеня логічної зв'язності (когезіi) загалом.

Таблиця 6. Середньогрупові результати ПЛА текстів перекладу програмою SPSS за синтаксичними показниками $(\mathrm{n}=40)$

\begin{tabular}{lcc}
\hline \multicolumn{1}{c}{ Variables } & $\begin{array}{c}\text { Mean } \\
(\text { SD) }\end{array}$ & $\begin{array}{c}\text { Min- } \\
\text { Max }\end{array}$ \\
\hline \multirow{2}{*}{ NCOORD } & 79.23 & 58.00 \\
& $(10.26)$ & 101.00 \\
NSUBORD & 90.23 & 52.00 \\
& $(10.03)$ & 118.00 \\
COHESION & .64 & .55 \\
& $(.052)$ & .79 \\
\hline
\end{tabular}

Примітка: Mеап=середньогрупові значення, SD=стандартне відхилення, Міп=мінімальне значення, Мах=максимальне значення, $n=$ =ількість українських перекладів

Тенденцію частішого маркування логічних зв'язків між реченнями зберігає у своєму перекладі i Ю. Покальчук. Для порівняння, COHESION у ВT становив 0,55 (табл. 7).

Таблиця 7. ПЛА синтаксичних показників тексту-оригіналу та перекладу Ю. Покальчука

\begin{tabular}{lcc}
\hline \multicolumn{1}{c}{ Variables } & J.D. Salinger & Ю. Покальчук \\
\hline NCOORD & 63.00 & 91.00 \\
NSUBORD & 58.00 & 53.00 \\
COHESION & .55 & .70 \\
\hline
\end{tabular}

Отже, дані (табл. 6-7) засвідчують прояв Д-закономірностей експліцитації й раціоналізації синтаксичних зв'язків, згаданих у загальному переліку зарубіжних фахівців (Chesterman, 2004; Berman, 1985; Olohan, 2002). Така тенденція властива була, передусім, представникам аналітичного КС та проміжного, аналітикосинтетичного КС.

\section{Висновки}

Психолінгвістичний зіставний аналіз текстів першоджерела, професійного перекладу Ю. Покальчука та перекладів новачків 
засвідчив зміни в лексичних, стилістичних i синтаксичних показниках цільових версій. Виявлено тенденції до імпліщ̧итаціï на стилістичному рівні через брак дискурсивних маркерів глобальної (тематичної) макроструктури в цільових версіях Ю. Покальчука та студентів, спрощуення на цьому ж рівні через зменшення кількості особових займенників, збільшення кількості речень унаслідок зменшення середнього обсягу речень у цільових текстах; нормалізації - зменшення питомої ваги прагматичних маркерів та заповнювачів пауз; експліu̧uтаuіï на лексичному рівні внаслідок збільшення коефіцієнтів лексичного розмаїття й щільності на лексичному рівні; раціоналізації на синтаксичному рівні в результаті введення більшої кількості сполучників сурядності й підрядності перекладачами-початківцями.

Здійснене дослідження Д-закономірностей у художньому перекладі має, безперечно, низку недоліків, серед яких слід назвати порівняно невелику кількість учасників емпіричного вивчення, а також порівняно невеликий обсяг проаналізованого художнього тексту. Водночас, спостережені Д-закономірності видаються такими, що мають вагу, позаяк спиралися на аналіз мовних одиниць носіїв процедурного значення, що стосуються способу обробки ВТ, що виключає аналіз випадків мовної інтерференції. Перспективним видається залучення до подальшого ПЛА «продуктів» професійних перекладачів iз використанням програми LIWC 2015, розширення паралельного двомовного корпусу, а також пошук i вивчення $Ц$-універсалій на основі вже створеного зіставного одномовного електронного корпусу.

\section{Література}

Засєкін, С.В. (2012). Психолінгвістичні універсалії перекладу художнього тексту. (Монографія). Луцьк: ВНУ ім. Лесі Українки.

Карасик, В.И. (1992). Социальный статус человека в лингвистическом аспекте. «Я», «Субъект», «Индивид» в парадигмах современного языкознания (с. 4774). Москва: ИЯ РАН.

Чередниченко, О.І. (2007). Про мову і переклад. Київ: Либідь.

Черноватий, Л.М., \& Карабан, В.І. (2007). Олександр Фінкель - забутий теоретик украӥнського перекладознавства. Вінниця: Нова книга.

Alves, F., \& Gonçalves, J.L. (2013). Investigating the conceptual-procedural distinction in the translation process. Target, 25(1), 107-124. https://doi.org/10.1075/ target.25.1.09alv 
Alves, F., Gonçalves, J., \& Szpak, K. (2014). Some thoughts about the conceptual/ procedural distinction in translation: a key-logging and eye-tracking study of processing effort. MonTI Special Issue - Minding Translation, 151-175.

Alves, F., Szpak, K.S., Gonçalves, J.L., Sekino, K., Aquino, M., Castro, R.A., et. al. (2016). Investigating cognitive effort in post-editing: A relevance-theoretical approach. In S. Hansen-Schirra \& S. Grucza (Eds.), Eyetracking and Applied Linguistics (pp. 109-142). Berlin: Language Science Press. doi: 10.17169/langsci. b108.296

Berman, A. (1985). La traduction et la lettre ou l'Auberge du lointain. Paris: Seuil.

Blakemore, D. (2002). Relevance and Linguistic Meaning: The Semantics and Pragmatics of Discourse Markers. Cambridge: Cambridge University Press. https://doi.org/10.1017/CBO9780511486456

Blum-Kulka, S. (1986). Shifts of cohesion and coherence in translation. In J. House \& S. Blum-Kulka (Eds.), Interlingual and Intercultural Communication: Discourse and Cognition in Translation and Second Language Acquisition Studies (pp. 1735). Tübingen: Gunter Narr.

Chesterman, A. (2004). Hypotheses about translation universals. In G. Hansen, K. Mlmkjær \& D. Gile (Eds.), Claims, Changes and Challenges in Translation Studies (pp. 1-13). Amsterdam: John Benjamins Publishing Company. https://doi. org/10.1075/btl.50.02che

Chesterman, A. (2011). Translation universals. In Y. Gambier \& L. van Doorslaer (Eds.), Handbook of Translation Studies (Vol. 2, pp. 175-179). Amsterdam: John Benjamins. https://doi.org/10.1075/hts.2.tra12

Dragsted, B. (2010). Coordination of reading and writing processes in translation. In G.M. Shreve \& E. Angelone (Eds.), Translation and Cognition (pp. 41-62). Amsterdam, the Netherlands/Philadelphia, PA: Benjamins. https://doi.org/10.1075/ ata.xv.04dra

Frawley, W. (1984). Prolegomenon to a Theory of Translation. In W. Frawley (Ed.), Translation: Literary, Linguistic, and Philosophical Perspectives (pp. 54-98). Newmark: University of Delaware Press.

Halverson, S.L. (1998). Translation Studies and representative corpora: establishing links between translation corpora, theoretical/descriptive categories and a conception of the object of study. Meta, 43(4), 631-651. https://doi. org/10.7202/003000ar

Hvelplund, K. (2017). Eye tracking in translation process research. In J.W. Schwieter \& A. Ferreira (Eds.), The Handbook of Translation and Cognition (pp. 248-264). New York: Wiley-Blackwell. https://doi.org/10.1002/9781119241485.ch14

Ireland, M. Slatcher, R., Eastwick, P., \& Pennebaker, J. (2011). Language style matching predicts relationship initiation and stability. Psychological Science, 22(1), 39-44. https://doi.org/10.1177/0956797610392928

Laviosa-Braithwaite, S. (1996). The English Comparable Corpus (ECC): A Resource and a Methodology for the Empirical Study of Translation. Manchester: Centre for Translation Studies, UMIST.

Nicolle, S. (1998). A relevance theory perspective on grammaticalization. Cognitive Linguistics, 9(1), 1-35. https://doi.org/10.1515/cogl.1998.9.1.1

Olohan, M. (2002). Leave it out! Using a comparable corpus to investigate aspects of explicitation in translation. Cadernos de Tradução, 9, 153-169. https://doi. org/10.1075/target.15.1.04olo 
Дослідження когнітивних і психолінгвальних рис перекладних...

Olohan, M., \& Baker, M. (2000). Reporting that in translated English. Evidence for subconscious processes of explicitation? Across Languages and Cultures 1(2), 141-158. https://doi.org/10.1556/Acr.1.2000.2.1

Paradis, M. (2004). A Neurolinguistic Theory of Bilingualism. Amsterdam: John Benjamins. https://doi.org/10.1075/sibil.18

Paradis, M. (2009). Declarative and Procedural Determinants of Second Languages. Amsterdam: John Benjamins. https://doi.org/10.1075/sibil.40

Pennebaker, J.W., Boyd, R.L., Jordan, K., \& Blackburn, K. (2015). The Development and Psychometric Properties of LIWC2015. Austin, TX: University of Texas at Austin.

Schiffrin, D. (1987). Discourse Markers. Cambridge: Cambridge University Press. https://doi.org/10.1017/CBO9780511611841

Smith, E., \& Senter, R. (1967). Automated Readability Index AMRL-TR. WrightPatterson AFB, OH: Aerospace Medical Division.

Toury, G. (1995) Descriptive Translation Studies - And Beyond. Revised edition. Amsterdam and Philadelphia: Benjamins. https://doi.org/10.1075/btl.4

Wilson, D., \& Sperber, D. (1993). Linguistic form and relevance. Lingua, 90(1), 1-25. https://doi.org/10.1016/0024-3841(93)90058-5

Wilson, D. (2011). The conceptual-procedural distinction: Past, present and future. In V. Escandell-Vidal, M. Leonetti \& A. Ahern (Eds.), Procedural Meaning: Problems and Perspectives (pp. 3-31). Bingley: Emerald. https://doi.org/10.1108/ S1472-7870(2011)0000025005

Zasiekin, S. (2014). Literary translation universals: a psycholinguistic study of novice translators' choices. East European Journal of Psycholinguistics, 1(1), 223-233. doi: 10.5281/zenodo.10605

\section{Джерела ілюстративного матеріалу}

Salinger, J.D. (1964). Franny and Zooey. N.Y.: Bantam Books.

Селінджер, Дж. (1984). Д. Френні: Повісті, оповідання. (Пер. 3 англ. Ю. Покальчука). Київ: Молодь.

\section{References}

Zasiekin, S. (2012). Psykholinguistychni Universalii Perekladu Khudozhnioho Tekstu [Psycholinguistic Universals in the Translation of Literary Texts]. Lutsk: Lesya Ukrainka Volyn State University [in Ukrainian].

Karasik, V. (1992). Sotsialnyi status cheloveka v lingvisticheskom aspekte [Human social status in linguistic aspect]. "Ya», «Subjekt», "Individ»v Paradigmakh Sovremennoho Yasykoznaniya [《I», «Subject», "Individual» in the Paradigms of Modern Linguistics] (pp. 47-74). Moscow: Institute of Linguistics of the Russian Academy of Sciences [in Russian].

Cherednychenko, O. (2007). Pro Movu i Pereklad [On Language and Traanslation]. Kyiv: Lybid [in Ukrainian].

Chernovatyi, L., \& Karaban, V. (2007). Oleksandr Finkel - Zabutyi Teoretyk Ukrainskoho Perekladoznavstva [Oleksandr Finkel - Forgotten Theoretician of the Ukrainian Translation Studies]. Vinnytsia: Nova Knyha [in Ukrainian]. 
Alves, F., \& Gonçalves, J.L. (2013). Investigating the conceptual-procedural distinction in the translation process. Target, 25(1), 107-124. https://doi.org/10.1075/ target.25.1.09alv

Alves, F., Gonçalves, J., \& Szpak, K. (2014). Some thoughts about the conceptual/ procedural distinction in translation: a key-logging and eye-tracking study of processing effort. MonTI Special Issue - Minding Translation, 151-175.

Alves, F., Szpak, K.S., Gonçalves, J.L., Sekino, K., Aquino, M., Castro, R.A., et. al. (2016). Investigating cognitive effort in post-editing: A relevance-theoretical approach. In S. Hansen-Schirra \& S. Grucza (Eds.), Eyetracking and Applied Linguistics (pp. 109-142). Berlin: Language Science Press. doi: 10.17169/langsci. b108.296

Berman, A. (1985). La traduction et la lettre ou l'Auberge du lointain. Paris: Seuil.

Blakemore, D. (2002). Relevance and Linguistic Meaning: The Semantics and Pragmatics of Discourse Markers. Cambridge: Cambridge University Press. https://doi.org/10.1017/CBO9780511486456

Blum-Kulka, S. (1986). Shifts of cohesion and coherence in translation. In J. House \& S. Blum-Kulka (Eds.), Interlingual and Intercultural Communication: Discourse and Cognition in Translation and Second Language Acquisition Studies (pp. 1735). Tübingen: Gunter Narr.

Chesterman, A. (2004). Hypotheses about translation universals. In G. Hansen, K. Mlmkjær \& D. Gile (Eds.), Claims, Changes and Challenges in Translation Studies (pp. 1-13). Amsterdam: John Benjamins Publishing Company. https://doi. org $/ 10.1075 / \mathrm{btl} .50 .02 \mathrm{che}$

Chesterman, A. (2011). Translation universals. In Y. Gambier \& L. van Doorslaer (Eds.), Handbook of Translation Studies (Vol. 2, pp. 175-179). Amsterdam: John Benjamins. https://doi.org/10.1075/hts.2.tra12

Dragsted, B. (2010). Coordination of reading and writing processes in translation. In G.M. Shreve \& E. Angelone (Eds.), Translation and Cognition (pp. 41-62). Amsterdam, the Netherlands/Philadelphia, PA: Benjamins. https://oi.org/10.1075/ ata.Xv.04dra

Frawley, W. (1984). Prolegomenon to a Theory of Translation. In W. Frawley (Ed.), Translation: Literary, Linguistic, and Philosophical Perspectives (pp. 54-98). Newmark: University of Delaware Press.

Halverson, S.L. (1998). Translation Studies and representative corpora: establishing links between translation corpora, theoretical/descriptive categories and a conception of the object of study. Meta, 43(4), 631-651. https://doi. org/10.7202/003000ar

Hvelplund, K. (2017). Eye tracking in translation process research. In J.W. Schwieter \& A. Ferreira (Eds.), The Handbook of Translation and Cognition (pp. 248-264). New York: Wiley-Blackwell. https://doi.org/10.1002/9781119241485.ch14

Ireland, M. Slatcher, R., Eastwick, P., \& Pennebaker, J. (2011). Language style matching predicts relationship initiation and stability. Psychological Science, 22(1), 39-44. https://doi.org/10.1177/0956797610392928

Laviosa-Braithwaite, S. (1996). The English Comparable Corpus (ECC): A Resource and a Methodology for the Empirical Study of Translation. Manchester: Centre for Translation Studies, UMIST.

Nicolle, S. (1998). A relevance theory perspective on grammaticalization. Cognitive Linguistics, 9(1), 1-35. https://doi.org/10.1515/cogl.1998.9.1.1 
Olohan, M. (2002). Leave it out! Using a comparable corpus to investigate aspects of explicitation in translation. Cadernos de Tradução, 9, 153-169. https://doi. org/10.1075/target.15.1.04olo

Olohan, M., \& Baker, M. (2000). Reporting that in translated English. Evidence for subconscious processes of explicitation? Across Languages and Cultures 1(2), 141-158. https://doi.org/10.1556/Acr.1.2000.2.1

Paradis, M. (2004). A Neurolinguistic Theory of Bilingualism. Amsterdam: John Benjamins. https://doi.org/10.1075/sibil.18

Paradis, M. (2009). Declarative and Procedural Determinants of Second Languages. Amsterdam: John Benjamins. https://doi.org/10.1075/sibil.40

Pennebaker, J.W., Boyd, R.L., Jordan, K., \& Blackburn, K. (2015). The Development and Psychometric Properties of LIWC2015. Austin, TX: University of Texas at Austin.

Schiffrin, D. (1987). Discourse Markers. Cambridge: Cambridge University Press. https://doi.org/10.1017/CBO9780511611841

Smith, E., \& Senter, R. (1967). Automated Readability Index AMRL-TR. WrightPatterson AFB, OH: Aerospace Medical Division.

Toury, G. (1995) Descriptive Translation Studies - And Beyond. Revised edition. Amsterdam and Philadelphia: Benjamins. https://doi.org/10.1075/btl.4

Wilson, D., \& Sperber, D. (1993). Linguistic form and relevance. Lingua, 90(1), 1-25. https://doi.org/10.1016/0024-3841(93)90058-5

Wilson, D. (2011). The conceptual-procedural distinction: Past, present and future. In V. Escandell-Vidal, M. Leonetti \& A. Ahern (Eds.), Procedural Meaning: Problems and Perspectives (pp. 3-31). Bingley: Emerald. https://doi.org/10.1108/ S1472-7870(2011)0000025005

Zasiekin, S. (2014). Literary translation universals: a psycholinguistic study of novice translators' choices. East European Journal of Psycholinguistics, 1(1), 223-233. doi: $10.5281 /$ zenodo. 10605

\section{Sources}

Salinger, J.D. (1964). Franny and Zooey. N.Y.: Bantam Books.

Salinger, J.D. (1984). Franny [Franny]. (Yu. Pokalchuk, Trans). Kyiv: Molod [in Ukrainian].

\section{АНОТАЦІЯ}

Переклад зазвичай уявляють як надійний фундамент мовного розмаїття, один із засобів здорового функціонування тієї мови, на яку перекладають. Однак іноді переклад здатен зашкодити цільовій мові через подекуди наявність рис так званого "третього коду» (Frawley, 1984). Ці "деформувальні тенденції» (Berman, 1985) руйнують чільову мову через долучення неприродних і чужих для неї форм, що викликають порушення на лексичному, стилістичному й синтаксичному рівнях. Це дослідження має за мету виявити ці деструктивні риси, яких традиційно в перекладознавстві іменують «перекладацькі універсалії» (Chesterman, 2004). Здійснено психолінгвістичний аналіз для 
Investigating Cognitive and Psycholinguistic Features of Translation...

визначення неконтрольованого з боку свідомості вживання перекладачами функціональних мовних одиниць із процедурним значенням. Згідно з теорією релевантності (Wilson \& Sperber, 1993), кодована змістовими словами концептуальна інформація виражає ідеї, а процедурна інфрормація сприяє виведенню імплікатур, способів обробки пропозичій. До групи носіїв процедурної інформації належать дискурсивні маркери, сполучники, прийменники, частки, займенники, модальні слова і $\mathrm{m}$. ін. Дослідження проводилося на матеріалі паралельного англо-українського корпусу, що містив оригінальний уривок із твору Дж. Селінджера «Френні» обсягом 8 тис. знаків, один професійний переклад та сорок текстів перекладу, виконаних студентами-перекладачами.

Лінгвальні дані корпусу досліджено на основі методу психолінгвістичного аналізу й піддано обробці комп'ютерними програмами Textanz ma SPSS.

Результати психолінгвістичного аналізу засвідчили наявність таких тенденцій: імпліцитації на стилістичному рівні через брак дискурсивних маркерів глобальної (тематичної) макроструктури в цільових версіях Ю. Покальчука та студентів; спрощення на цьому ж рівні через зменшення кількості особових займенників, збільшення кількості речень унаслідок зменшення середнього обсягу речень у цільових текстах; нормалізації - зменшення питомої ваги прагматичних маркерів та заповнювачів пауз; експліцитації на лексичному рівні внаслідок збільшення коефіцієнтів лексичного розмаїття й щільності на лексичному рівні; раціоналізації на синтаксичному рівні в результаті введення перекладачами-початківцями більшої кількості сполучників сурядності й підрядності.

Висновки. Загалом, одержані результати проливають світло на розуміння того, як способи перероблення процедурної інформації майбутніми перекладачами мають прояв у перекладі.

Ключові слова: теорія релевантності, перекладні закономірності, процедурне/ концептуальне значення.

\section{Засекин Сергей. Исследование когнитивных и психолингвальных особенностей переводных закономерностей}

\section{АННОТАЦИЯ}

Перевод обычно представляют как надежный фундамент языкового разнообразия, одно из средств здорового функционирования того языка, на который переводят. Однако иногда перевод способен повредить целевому языку благодаря наличию черт так называемого "третьего кода» (Frawley, 1984). Эти «дерормирующие тенденции» (Berman, 1985) разрушают целевой язык из-за привнесения неетественных и чуждых для нее фрорм, вызывающих нарушения на лексическом, стилистическом и синтаксическом уровнях. Настоящее исследование имеет иелью выявить эти деструктивные особенности, которые традиционно в переводоведении называют "переводческие универсалии» (Chesterman, 2004). Проведен психолингвистический анализ для определения неконтролируемого со 
стороны сознания употребление переводчиками функциональных языковых единиц с процедурным значением. Согласно теории релевантности (Wilson \& Sperber, 1993), кодированная содержательными словами концептуальная информация выражает идеи, а процедурная информация способствует выводу импликатур, способов обработки предложений. $K$ группе носителей процедурной информации относятся дискурсивные маркеры, союзы, предлоги, частицы, местоимения, модальные слова и т. д. Исследование проводилось на материале параллельного англо-украинского корпуса, содержащего оригинальный отрывок из произведения Дж. Сэлинджера «Фрэнни» объемом 8 тыс. знаков, один профессиональный перевод и сорок текстов перевода, выполненных студентами-переводчиками.

Лингвальные данные корпуса исследовались на основе метода психолінгвистического анализа с последующей обработкой компьютерными программами Textanz и SPSS.

Результаты психоингвистического анализа подтвердили присутсвие следующих тенденцій: имплицитации на стилистическом уровне из-за недостаточности дискурсивных маркеров глобальной (тематической) макроструктуры в целевых версиях Ю. Покальчука и студентов; упрощение на этом же уровне из-за уменьшения количества личных местоимений, увеличение количества предложений вследствие уменьшения среднего объема предложений в целевых текстах; нормализации - уменьшение удельного веса прагматических маркеров и заполнителей пауз; эксплицитации на лексическом уровне вследствие увеличения коэффициентов лексического разнообразия и плотности на лексическом уровне; рационализации на синтаксическом уровне в результате введения начинающими переводчиками избыточного количества союзов сочинительной и подчинительной связи.

Выводы. Таким образом полученные результаты способствуют лучшему пониманию того, как способы обработки процедурной информации будущими переводчиками проявляются в переводе.

Ключевые слова: теория релевантности, переводные закономерности, процедурное/концептуальное значение. 